\title{
'With the back of an axe': Reading the Group Architects'
}

JOHN NEWTON

\section{Family reunion}

The emergence of New Zealand cultural nationalism has traditionally been narrated in literary terms. It was writers who put the first pegs in the ground and who articulated the programme most forcefully and most enduringly; and it's Curnow, Sargeson, Brasch and company who always come first in the roll-call of nationalist movers and shakers, and whose themes and vocabulary still set the terms for representing a new intent in settler culture from the early 1930s. Painting runs a comfortable second (McCahon, Woollaston, Angus), but viewed very much through a literary lens. With music in third place (Lilburn, solo) the cast of the conventional family narrative is complete.

Accordingly it makes for an interesting encounter when a new scholarly discourse comes to the table. Group Architects: Towards a New Zealand Architecture (2010), a handsome historical and critical anthology expertly edited by Julia Gatley, offers precisely this kind of intervention. I'm speaking myself as a literary reader, and any comments I risk about architectural historiography must be, at best, provisional. But architecture has seldom figured in the wider discourse on mid-century nationalism, and even within the discipline itself, as Paul Walker and Justine Clark observe, the profile of those architects loosely known as the Group appears to have been more an effect of mythology than of systematic analysis. ${ }^{2}$ On more than one front, then, this book is news, but the issues I want to address relate to that default understanding of nationalism whose terms are pre-eminently literary. To hear Bill Wilson, the Group's most charismatic thinker, exclaim in 1948 that 'New Zealand doesn't exist' ${ }^{3}$ is rather like meeting a long-lost adult relative a half-sibling, say, who suddenly appears on the doorstep - complete with uncanny and entrancing resemblances, and with a suitcase full of questions to be asked on both sides. Can the stranger be quietly assimilated into the time-honoured family legend? Or might this familiar 'other' oblige us to rearrange the furniture?

\section{From Phoenix to Planning}

The first announcement of the new literary nationalism can be dated quite precisely. In March 1932 the first of four issues of Phoenix was published 
by the Literary Club of the Auckland University College. The editor of the first two numbers was 21-year-old English student James Bertram (b.1910); the printer was Bob Lowry (b.1912); contributors included Charles Brasch (b.1909), Allen Curnow (b.1912) and the slightly older R.A.K. Mason (b.1905) who would edit issues three and four. Among the journal's ambitions, the opening editorial listed 'the integration of national consciousness, the focusing of contemporary opinion upon local needs, the creation of cultural antennae, the communication of definite standards of taste', ${ }^{4}$ a knowingly 'grandiloquen[t]' agenda but one that the writers associated with Phoenix would advance considerably by the end of the 1940s.

The appearance of equivalent ambitions in architecture can be located with equal precision. In April 1946 another group of Auckland students, second-year architects, signed the constitution of the Architectural Group; this was followed the same year by the single issue of the magazine Planning, and a manifesto, 'On the Necessity for Architecture': '. . . overseas solutions will not do. New Zealand must have its own architecture, its own sense of what is beautiful and appropriate to our climate and conditions'. ${ }^{5}$ From this early beginning in print, original members, and others, would go on to form a sequence of firms - Group Construction Company (1949-51), Group Architects (1951-63), Wilson \& Juriss (1963-68) - the work of which, along with various diasporic ventures, can sensibly be discussed under the umbrella of 'the Group'.

The principal author of the constitution and the manifesto, and effective editor of the journal, ${ }^{6}$ was Bill Wilson (b.1919). At 27, a returned serviceman, Wilson was a few years older and more experienced than the rest (somewhat like Mason among the Phoenix circle), but the other players listed in Gatley's roll-call were all barely in their twenties: Campbell Craig (b.1927), James Hackshaw (b.1926), Marilyn Hart (b.1927), Ivan Juriss (b.1924), Barbara Parker (b. ca 1925), Bret Penman (b.1927), Bruce Rothheram (b.1926), Bill Toomath (b.1925) and Allan Wild (b.1927). ${ }^{7}$ I emphasize these dates of birth to make a simple but important point: the Group were second generation nationalists. They matched the Phoenix group move for move but they did so fifteen years later; their literary coevals were not Curnow, Brasch and Sargeson but the younger writers who followed and in different ways challenged them - Maurice Duggan, Janet Frame, James K. Baxter, Kendrick Smithyman - a second wave, born in the decade after the First World War. Fifteen years is a 'short' generation. But in this case it introduces two key points of difference: firstly, this second-generation cohort had room to build on the prior initiatives of the Thirties; secondly and crucially, especially for the architects, they reached early adulthood downstream from the Depression and the Second World War. 


\section{'New Dreamland'}

A crisis in the nation's housing stock had been acknowledged for as long as anyone could remember. The first tentative ventures into state housing as a remedy went all the way back to the Seddon administration and the Workers' Dwellings Act of $1905,{ }^{8}$ though it was the first Labour government which, from 1936, made state housing into its own signature enterprise. Despite much-heralded achievements in the initial years of the programme, however, by 1943 the demands of the war had seen production of new state houses fall almost to zero. The war's end left a shortage of building materials, a shortage of architects and tradesmen, and brought the pressure of returning servicemen keen to start new families. By 1946 the official backlog stood at 26,000 homes. ${ }^{9}$ One response was to try to divert the de-mobilizing labour force into the building industry; to this end, for instance, Ernst Plischke was enlisted to produce the educational bulletin for servicemen that would later become Design and Living. ${ }^{10}$ Housing, then, was a hot issue. In 1946 enrolments at the Auckland School of Architecture rose from 62 to 104 (with 48 first-year students). In the struggle to accommodate them, teaching had to be shifted to decommissioned army huts. ${ }^{11}$

For budding postwar architects, this sense of material urgency at home was matched by an aesthetic excitement filtering through from the northern hemisphere. The School itself may have been contemptuous of international modernism - a situation that by 1948 would lead to full-scale student revolt $^{12}$ - but through textbooks like J.M. Richards' An Introduction to Modern Architecture (1940) and journals like Architectural Review, the Group students took in all they could find about Gropius, Le Corbusier and Mies van der Rohe. Like Curnow's generation, the Group emerged at a point where specific local pressures met the implications of the global modernist experiment. But the 15-year time-lag once again had repercussions. The Group could look to architects who had adapted the extreme formalism of the international style to particular local environments: to Frank Lloyd Wright, for example, and Alvar Aalto. And in English immigrant Vernon Brown (b.1905) they had a teacher already committed to a pragmatic New Zealand modernism. The one inspiring voice in an otherwise dispiriting programme, Brown would be lauded by Bill Wilson as 'the only man in New Zealand to have produced a coherent, consistent and liveable canon of domestic architecture'. ${ }^{13}$

Brown was a conduit for Aalto's work: with their flat roofs, creosotestained weatherboards and white-painted timber detailing, Brown's own houses showed the Finnish master's influence quite explicitly. But he was also a channel for the first wave of local cultural nationalism. A.R.D. Fairburn's friendship with Brown was among the most important of the poet's life. ${ }^{14}$ Fairburn lectured to Brown's students, and would soon be among the 
Group's most prominent advocates. Brown for his part designed houses for a number of nationalist writers, including R.A.K. Mason, Maurice Duggan and an unbuilt proposal for Frank Sargeson. Duggan could refer to himself, parodically, as 'You know . . . young writer in a vernon brown garret, the G. N. Z. N [Great New Zealand Novel], ${ }^{15}$ as if the Brown house had now become a standard nationalist insignia. Though Brown's own career was held in check by the Depression, and although he is not typically named in this context, clearly he is a voice of that nationalist first wave. We needn't be surprised, then, if his students strike familiar attitudes.

To anyone for whom 'nationalism' evokes an image of naïve cheer-leading, Allen Curnow's version is a calculated affront. Alex Calder usefully calls it critical nationalism: it is a paradoxical project that affirms New Zealand as 'real' by dismantling and excoriating a history of failure to inhabit the place truthfully. ${ }^{16}$ As nationalism in a modernist key, its tone is staunchly disillusioned. The primary task is bulldozing the site, while the building of some new structure (what Curnow calls, typically, an 'anti-myth') is a secondary move grounded in the rigour of that initial critique.

Sometimes Bill Wilson sounds so much like Curnow that it's hard to tell whether he is deliberately (or perhaps unconsciously) echoing him, or whether it's just a matter of two writers meeting at the same historical crossroads. Either way, Wilson follows that critical nationalist strategy to the letter. The initial note, therefore, is one of disaffection, as in the opening statement of the Group's manifesto, 'On the Necessity of Architecture':

We New Zealanders live in a chaos of unplanned speculative building under an unthinking, self-seeking system of land subdivision. Our suburbias spread their tentacles along all the city traffic routes....; our homes are ill-planned, graceless and monotonous in their petty variety. ${ }^{17}$

The ultimate destination may be an affirmation of the local - '[O]verseas solutions will not do. New Zealand must have its own architecture, its own sense of what is beautiful and appropriate to our conditions' - but this presupposes a reality check, an overdue reckoning with our present unreal condition. In 'The Small House' (1948) New Zealand (or as Wilson prefers it, 'New Dreamland') is reduced to a consumerist hallucination:

New Zealand doesn't exist. Not now even a long white cloud, just erewhon. Somehow life escaped, slid out of the real world into the Dream. ... .

Our little romance: God's Own Country and the three-piece suite. 'House the worker (?) like a millionaire.' Let's all live like J.P. Morgan, coney coats and frigidaires. ${ }^{18}$

The 'small house' of the title is a refusal of this 'national illusion'. Turning its back on the grandiloquent dream of everyone living like J.P. Morgan, 
it authenticates itself by its contrasting modesty and pragmatism. Instead of working backwards from consumerist fantasies, the architect 'must identify himself with the real, with the reality which lies behind our Dream':

Beneath our lives there is a discoverable pattern of coming and going,

of moving in space. This pattern of movement becomes the plan of the house . . The architect does not invent plans - he discovers them. ${ }^{19}$

Beginning with the client's daily life ('the reality prior to the house', to misquote Curnow), '[t]he architect translates real needs directly into real building.'

For all this despair at the existing state of play ('there is no architecture in New Zealand. NONE!'), the houses that the Group built in the late 1940s were not without local precedent. As Francis Pound has explained, there is a habit in nationalist (and modernist) rhetoric of rejecting the immediate past at the same time as reaching back to more safely distant antecedents with which to affiliate oneself. ${ }^{20}$ Nationalist art critics have preferred the so-called 'stark realism' of topographic painters like Heaphy and Buchanan to the later, more romantic idiom of Gully and Hodgkins. Curnow maintains that the poets of his own generation are 'more truly descended' from the writers of the 1890s than from 'the altogether sentimental twilight which intervened'. ${ }^{21}$ In architectural discourse, as Walker and Clark explain, the equivalent historical narrative was already well-entrenched by the time the Group arrived (in fact it shows up as early as 1900). ${ }^{22}$ An early pioneer ideal ('utilitarian, timber, simple') gives way, over time, and with the onset of prosperity, to various forms of confusion and misguided ostentation. Architecture, the story goes, needs to rediscover the honesty, the functionalism, the responsiveness to climate and conditions of Maori housing, the pioneer shack and the first settler homes.

The Group didn't belabour this narrative themselves, although Barbara Parker repeated it in an essay of $1949 .{ }^{23}$ But then they didn't really need to: this account was so entrenched that the government itself was recycling it in the thinly disguised electioneering of the 1946 National Film Unit production Housing in New Zealand. When the Group's own houses appeared, with their exposed beams and rafters, their open-plan living spaces, their timber, creosote and corrugated iron, the resonance wasn't difficult to spot. You didn't need to know that Bill Wilson's first building had been a cowshed designed for his father-in-law in Otaki ${ }^{24}$ to sense that, behind the encompassing aura of simplicity and economy, lay not just modernist rationalism but a residual Kiwi pragmatism. Fairburn, who had already repeated the 'fall from simplicity' narrative in his 'By Way of Introduction' in Planning, ${ }^{25}$ drew on it again when tracing the so-called Second House (1949) back to 'the simple rectangular form of the Maori meeting house'. ${ }^{26}$ James Garrett, a few years later, would welcome the Group as 'new pioneers' ${ }^{27}$ Others like 
Plischke and Nicholas Pevsner would give the same affiliation a negative spin; from their European perspective, this appeal to the vernacular was a regression from the pure, placeless formalism of Mies and Le Corbusier (not to mention Plischke himself). ${ }^{28}$ But the tide of cultural nationalism was running strongly in the Group's favour, and would do so until as late as the early 1980s (David Mitchell and Gillian Chaplin's salute to the Kiwi vernacular, The Elegant Shed, appeared in 1984).

\section{North Shore nationalism}

In 1949 the Group students, recently graduated, were the beneficiaries of an inspired piece of patronage. Bret Penman's father Robert bought a double section in Takapuna and invited the tyro architects to build on it. The Group Construction Company was formed, ${ }^{29}$ and duly built the experimental dwellings known today as the First and Second Houses, on the Penman property $(1950,1951)$, and a third designed by Bruce Rotherham in nearby Stanley Bay (1950-51). The Takapuna location could not have been more apt, for here was unquestionably the hub of postwar cultural nationalism. When Fairburn was preparing his Listener article on the Second House he only had to walk round the corner from his own home in Devonport. Sargeson, in Esmonde Rd, was closer still, in the iconic dwelling built for him by another Takapuna identity and Group friend and collaborator, George Haydn. When Wilson name-checks Sargeson in 'The Small House,' the fact that the reference seems more-or-less gratuitous implies that the gesture is primarily one of affiliation. Certainly members of the Group were among those who converged on Esmonde Rd, a connection possibly established through Haydn, or possibly through outer-circle Group associate Renate Prince, first (and perhaps most fondly remembered) of all the tenants of Sargeson's legendary army hut. At Esmonde Rd, of course, they would have been likely to cross paths with second-generation nationalists from the writing fraternity - people like Maurice Duggan, who published 'The Small House' in Kiwi, and lived in his Vernon Brown 'garret' a little further north in Milford.

Less often associated with the Takapuna scene is Allen Curnow, but the Curnows too moved to the North Shore in the early 1950s. In fact the home they moved into, in Herbert Street, Shoal Bay, was built (originally for Brian Donovan) by none other than Vernon Brown. Almost next door was Ivan Juriss, living with his family in an octagonal hut while he built in nearby Stanley Bay, and Wystan Curnow recalls another Group house in neighbouring Jutland $\mathrm{Rd}^{30}$ It is not entirely clear how aware Curnow Snr was of the Group's activities, and there is little record of his fraternizing with the Takapuna literary set. But he was certainly aware of modernist architecture, being a keen admirer of Plischke, and having been desperately disappointed, on first moving to Auckland in 1951, not to be able to purchase 
a spec-built Jack Abbott house that in Curnow's description sounds distinctly Group-like. ${ }^{31}$ One thing, in any case, that Curnow's presence does confirm is that by the end of the 1940s cultural nationalism's centre of gravity had shifted decisively to Auckland's North Shore. Christchurch had suffered a debilitating exodus (Curnow, Glover, McCahon, Angus, Baxter, Pearson, Lilburn and Page had all moved North in the space of a few years), and in Wellington younger writers like Baxter were increasingly opposing the kind of nationalism represented in Curnow's poetry anthologies. But on the North Shore the localist vision was now the joint project of two generations: older nationalist writers; younger nationalist writers (Duggan, Sinclair, Smithyman, and a little later Frame and Stead); and a cohort of younger architects rubbing shoulders with both.

In his introductory remarks in Planning, Fairburn makes a characteristic complaint: 'The architect has become too much of a gentleman. To take off his coat and climb on a wall with a plumbline would so lower his dignity that he could no longer look the builder's apprentice in the eye'. ${ }^{32}$ Where the Group were concerned, though, he needn't have worried: four years later, in his Listener essay on the Second House, he was able to applaud them for having become their own carpenters. ${ }^{33}$ Posing for the camera in front of the newly completed building, or leaning over a sawhorse, saw and cigarette in hand (Juriss), ${ }^{34}$ it's as if these young men have been summoned out of the nationalist imaginary. One could hardly conjure a plainer embodiment of the ideal that Kai Jensen dubs the 'whole man': the artist or intellectual who lends authority to the nationalist movement by measuring up, not just creatively, but against vernacular codes as well..$^{35}$

Nationalism was always meant to be built with the bare hands, and the Group appeared to meet this demand both in their houses and in their habitus. Legend has it that Wilson's 'The Small House' was dashed off at a drinking session at the local intelligentsia's unofficial HQ, the Kiwi (to be published, fittingly enough, in the magazine of the same name by exemplary literary boozer Maurice Duggan). The story may well be too good to be true. But of course that's the point: it's the right kind of story. Or consider Wilson's 1954 comments on the Wellington Architectural Centre's Design Review. Lamenting the persistence of 'whimsy and generalization' - where have we heard that before? - he writes:

... a magazine published by a responsible architectural society has a clear and urgent duty to present a sharp, frank criticism, proceeding from clearly stated and constantly reiterated values and driven home with the back of an axe. ${ }^{36}$

Realist, trenchant, vernacular-friendly; also, in the almost inevitable manner of its day, demonstratively macho: no Caxton poet could have put it more succinctly. 


\section{The city like a lover}

Despite sitting so firmly within the established nationalist fold, in one respect the Group seemed intent on broadening the paradigm. First-generation nationalism was emphatically anti-urban, modelling its national image only on the most select locations: the bush, the farm, the small town. As Francis Pound explains, this ideological division of space (the wicked City and the virtuous Country) has a long genealogy in pastoral and more recently post-industrial ('Romantic') conventions. ${ }^{37}$ But here it's tuned to a specific agenda of national individuation. That New Zealand offered a refuge from the Satanic Mills of industry was a myth that, throughout the history of the colony, had called for non-urban representations. However, Curnow, Holcroft and others imparted a new spin: 'the greater and remoter features of the landscape' (typically seen as hostile to the point of being barely inhabitable) now become the 'plane of reality' on which to discover, not colonial fantasy, but the new locality's real difference - an encounter that promises to burn off the mists of Romantic sensibility and Victorian selfimportance. ${ }^{38}$ Then there are the social relations supposedly promoted by this rugged environment. The bush, the farm, the rural settlement and work camp are the spiritual home of an egalitarian ethos imagined as transcending the inequities of British class relations. Settler vernacularism always carries this mythical surplus (egalitarianism as testament to national individuation); and its privileged settings are invariably non-urban, even while, as Pound reminds us, pastoral mythology conveniently screens the real insistence of rural capitalism.

Ironically enough, this arcadian fiction was being fashioned by urban intellectuals and artists from inside a rapidly urbanizing society. ${ }^{39}$ Not that this negates it, of course; even if Curnow preferred to think otherwise, we are talking about a myth, not sociology or history. Nonetheless, anti-urbanism was not the only vocabulary for thinking about the 'real' New Zealand of the Thirties and Forties. To architect Cedric Firth, for example, writing in Tomorrow in 1936, the nation's most pressing reality was apparent, not among the 'remoter features of the landscape', but in urban slums whose 'ugliness and tastelessness' were evidence, precisely, of 'the relentless energy characteristic of times of industrial expansion'. ${ }^{40}$ Describing Freeman's Bay and Te Aro, Firth (in the best tradition of left-wing 'muck-raking') confronts his readers with the nightmare antithesis of the nationalists' depopulated sublime:

In these dreary and depressing areas overcrowding is rife in every department of the housing operation; houses without room enough, or air enough or sun: houses without water: dark, dirty, damp and buginfested. Congestion of people in rooms; . . . honeycomb rookeries; overcrowding of land by buildings and the endless multiplication of 
residential blocks with only the slenderest intervening slice of open area or breathing space.

More desolate areas it is difficult to imagine: rambling, rotting districts littered with houses; dreary wastes where decrepit houses lean at angles offensive to our rectilinear eyes, and thrusting haphazard into this desolation are factories and warehouses, coal yards and rubbish dumps. ${ }^{41}$

It's not as if this slum-scape was entirely unrepresented in the creative literature of the period. It appeared in the work of leftish writers outside of or marginal to the nationalist project - John A. Lee, for example, and Robin Hyde. But for the nationalist A-team, now headquartered on the North Shore, reality had always been elsewhere.

The solution, in Firth's view, must be radical: 'If housing is to be done at all it cannot be a patchwork. It is more than a reform. It is either an entirely new way of providing a new standard of city environment or it is nothing at all.' The models he proposed were those of Vienna and Weimar Germany; but this wholesale, tabula rasa approach was common currency in the inter-war years, exemplified in the work of the CIAM (Congrès International d'Architecture Moderne) and most famously, Le Corbusier (La Ville Radieuse, 1935; The Athens Charter, 1943). Architecture needed to address the 'big picture': not houses, but neighbourhoods; not just individual needs, but those of new communities whose relations it would orchestrate. Never has confidence in utopian urban planning been higher than at this mid-point in the twentieth century. An aspiring modernist architect who took as a model Le Corbusier in Chandigarh or (a little later) Oscar Niemeyer in Brasilia, might imagine not just designing buildings, but planning entire new cities.

By 1946, the familiar call for slum-clearance and the modernist emphasis on rational oversight were being amplified still further by the sentiments of postwar regeneration (the need to 'rebuild after the War', the duty to provide homes for ex-servicemen to raise families). This was the atmosphere in which the Group were calling for a distinctive New Zealand architecture. Not for nothing was the journal called Planning. Its sights were set higher than mere 'building' or 'design.' The single issue opens with an epigraph from American architectural scholar Lewis Mumford:

Alberti describes the architect, not as a mere designer of buildings, but as a master of form; he drains swamps, he bores through mountains, he forms harbours, he provides buildings for public health, he builds cities. In short, the architect for Alberti is an engineer and a city planner, no less than a designer of individual houses and palaces. No smaller definition will suffice. Anything less is the notion of decorators ... 
In a nationalist context this imagery makes interesting reading. On the one hand the architect is a 'new pioneer', a drainer of swamps and a dredger of harbours. But as a builder of cities, his horizon is ultimately urban. Thus, inspired by the imperative to build a better urban New Zealand, and by the utopian call of 'planning' (as against the trivial ambition of '[b]uilding nice houses for nice people [which] is not architecture'), the Group appeared set to challenge the anti-urbanism of the nationalist paradigm.

In a tribute to Bill Wilson, Jack Lasenby remembered his enthusiasm for 'that never-ending subject, the City'. ${ }^{42}$ We can sense what he means from an article Wilson wrote for the New Zealand Herald. What is striking about 'Art and Architecture: Place For Beauty In a City' is its hitching of national identity to urbanity: 'Every great city expresses, more than any other man-made thing, the character of its people. ${ }^{43}$ Auckland in this respect is a wasted opportunity:

Auckland grows. Auckland is a respectable city. But behind all the clatter and chatter of the mechanics, technologists and administrators something is missing. That something is an art and architecture of our own without which we remain infantile, and the voice of our nationhood, unheard.

The solution? We must lie with the city like a lover.

Great cities demand our respect and our allegiance; beautiful cities our affection. Cities that are beautiful or great are good to be in. By their nobility and their beauty they move us. Through the pride or the love we feel for them they appeal to what is most admirable or likeable in ourselves.

We make the city in our small way, and the city more largely makes us. The city responds to our love, our pride, our despite or brutality, and repays us in kind a hundredfold. But a city, like a woman, cannot endure indifference, to be taken for granted - as we take Auckland.

This amorous metaphor (which runs for half a dozen paragraphs) may not strike us now as particularly fortunate. But its resonance with the gendered landscape tropes of the nationalist poets - that it's not the gaunt hills but the concrete canyons that call for our 'quiet and assiduity' - underlines the difference that an urban orientation introduces to a nationalism governed up to this point by literature and painting.

\section{Utopianism in the capital}

And yet, what did the Group, in their various incarnations, actually build? The answer has to be that, despite their more encompassing ambitions, they mostly built houses. To clarify the point, it's worth turning our attention briefly to Wellington. For if utopian modernism in the Corbusian vein had tangible outcomes in New Zealand, the place to look for them is in the 
capital, in the Housing and Planning divisions of the Ministry of Works, and in the Wellington Architectural Centre.

A key figure here is Gordon Wilson (1900-59), chief architect in the Department of Housing Construction established by the first Labour government in 1936 (later, the Housing Division of the Ministry of Works); and then from 1952 until his death, government architect. ${ }^{44}$ As Gatley has indicated, Wilson's reputation is hard to disentangle from that of Austrian refugee Ernst Plischke. ${ }^{45}$ Because the two came into conflict, and because the Plischke legend portrays him (rightly or otherwise) as a victim in New Zealand of neglect and xenophobia, it is difficult to see Wilson's contribution clearly in the glare of Plischke's current high profile. To his credit, though, it was Wilson who recruited Wellington's refugee architects: not only Plischke, but Helmut Einhorn, Friedrich Neumann (Fred Newman), Ernst Gerson, Fritz Farrar, Richard Fuchs. And it was under Wilson's direction that modernist ideas about public housing came closest to realization here. His own Berhampore Flats (1939-40) signalled the first notable departure from the detached state house ideal. Five substantial slab-apartment buildings quickly followed: most strikingly, and famously, the Dixon Street Flats (194144), the credit for which is now disputed between advocates for Wilson and Plischke.

Another important feature of Wilson's regime is the close collaboration he encouraged between architects and town-planners. Plischke and Helmut Einhorn, for instance, worked at times in both the Housing Division and the Planning Division. The two divisions shared adjoining spaces on the top floor of a government building known as the Tomato House, and it was these shared premises that Wilson made available as the initial home of the Wellington Architectural Centre. Established in 1946 (notable names among the initial membership include John Cox, George Porter, Ian Reynolds, Graham Dawson, Wilson, Einhorn, Plischke and Farrar), the Centre would be influential both as a teaching institution and as an advocate for progressive urban planning.

Among the Centre's teaching activities were not just evening lecture series, but intensive, project-based summer schools. The summer school of 1948-49 produced a student-designed Demonstration House, analogous to and exactly contemporary with the Group's ('First') experimental house in Takapuna. But the previous year's project had a quite different focus: 'Te Aro Replanned' was a utopian reimagining of central Wellington, addressing the slum described by Firth with the planning principles adumbrated by Le Corbusier et al. The results are striking, if not a little hair-raising: an entire central city built on the white geometric model of the Dixon Street Flats. As Paul Walker observes (referring to its 'grandiose tabula rasa mentality'), its rationalistic clustering of urban functions is predicated on bulldozing, not 
just the entire built environment, but the inner-city working class culture that inhabits it. ${ }^{46}$ The public, however, was fascinated. Exhibited at the Wellington Public Library, the students' model city drew twenty thousand visitors. A carefully staged publicity campaign saw it widely reviewed (notably by John Cox in the new nationalist 'house journal', Landfall), discussed in the media, toured to Auckland and beyond, and even displayed at the opening of the 1948 parliamentary session. That the work was done largely in the Tomato House ${ }^{47}$ is indicative of a relationship between architecture and government that could only be imagined in the capital city.

\section{The Group as 'public' architects}

At this point, to literary readers the story once again sounds oddly familiar: Auckland/Wellington, nationalism/internationalism, the Fifties and the Curnow-Baxter feud. But regional divisions in postwar architecture can be exaggerated. Five of the six signatories of the original Group constitution were in fact Wellingtonians and as students a number spent their summers in the capital (Wild and Toomath both took part in Te Aro Replanned). Part of the rationale for the Architectural Centre's teaching programme was to support students enrolled long-distance at Auckland who were not getting face-to-face instruction; it bolstered the Auckland programme as much as it may have implicitly questioned it. In subsequent years Wild and Toomath would both remain involved in the Architectural Centre (Wild served a term as president) ${ }^{48}$ and Toomath in particular would do his most important work in the capital.

Meanwhile, in Auckland, as Gatley rightly emphasizes, Wilson and others were keenly interested in the same civic issues as architects in Wellington. Wilson inveighed against suburban sprawl, the emphasis on motorways and reliance on cars; he argued for mixed residential development and eloquently championed the attractions of an urbanized culture. Eventually, in 1965, the Auckland Architecture Association was formed along similar lines to the Wellington Architectural Centre. In a chapter devoted to 'the public and commercial realm', Gatley argues that while '[t]he Group are not known for their concern with the urban realm . . . this is more a repercussion of history's fixation with their houses than an accurate reflection of the key players, their interests and their activities'. ${ }^{49}$

And yet, on the evidence offered here, it's not clear that this historical emphasis has been entirely misplaced. It's true that, individually and collectively, the Group cohort produced a variety of non-domestic buildings. In Wellington these included some major projects: Alan Wild designed Jellicoe Towers, while Bill Toomath's best-known work, the Wellington Teachers' Training College in Karori, is part of a much larger portfolio of educational buildings from Toomath \& [Derek] Wilson. In Auckland too, 
Group Architects firstly, and then Wilson \& Juriss, completed numerous projects that went beyond the domestic realm: kindergartens, ambulance stations, small residential blocks, and two handsome commercial buildings both designed as trade union offices. However, their efforts to break out into larger, more public projects were largely unsuccessful. Their one venture into high-density housing, the Devonport Naval Scheme (brokered again by Robert Penman hard on the heels of the first two houses), was a disappointing experience: when the government architect's office became involved the changes that were imposed left them feeling both financially short-changed and aesthetically frustrated..$^{50}$ There would be no further involvement in state-funded housing. Nor would Group Architects or Wilson $\&$ Juriss be successful in any of their major competition entries (the Sydney Opera House, the Otago University Library and others), or in private efforts to design larger-scale apartment buildings. If the Group's most characteristic work remains principally domestic, it wasn't for lack of will. Significantly, though, in Gatley's other recent major publication Long Live the Modern: New Zealand's New Architecture 1904-1984 (2008), only the Wellingtonians, Toomath and Wild, are represented by anything other than detached suburban houses.

In as much as the Group aspired beyond the merely domestic ('Building nice houses for nice people') and towards a broader practice of architecture - more holistic, more civic, more urban - two things told against them. One is the geographical factor: a fruitful engagement with the public sector (as seen in the Architectural Centre) could really only happen in Wellington. The second relates to the demographics that I canvassed near the outset; in other words the Group were just too young to have caught the most stimulating years in the Ministry of Works. Those who were prominent in the Ministry in that decade or two that saw the boldest negotiations between the state and urban modernism, were usually closer in age to the first generation of cultural nationalists: Gordon Wilson (b.1900), John Cox (b.1902), Ernst Plischke (b.1903), Cedric Firth (b.1908), Fred Newman (b.1900), Helmut Einhorn (b.1911). ${ }^{51}$ To them fell the chance of designing, not just those large modernist apartment buildings, but new towns and subdivisions, power stations and motorways. People like Newman and Einhorn made real the kinds of careers proposed by Mumford/Alberti: they 'drain[ed] swamps' and 'bore[d] through mountains'; they really were 'engineers' and 'city planner[s]'. But with the onset of the 1950s the atmosphere dimmed. In particular, the brief window of enthusiasm for the modernist apartment complex closed, a victim, it would seem of the government's sensitivity to the electorate and to the latter's presumed attachment to suburban neo-arcadia. In 1949 National was elected on a promise to transfer state houses into private ownership.

Though Wild and Bill Wilson had both worked for the Ministry before they first enrolled at Auckland, to the best of my knowledge no one from 
the inner Group ever re-joined it. Certainly no one emulated Jim Beard, a couple of years ahead of the Group at Auckland and a personal friend to many of them. Beard joined the Ministry, added a planning qualification to his architecture degree, and like his friend Einhorn worked across both disciplines. But through all the shifting formations, the various members of the Group remained in private practice. Those who added a public service dimension to their careers did so not through the Ministry of Works, but through the universities: Toomath at Wellington Polytechnic; Wilson, Hackshaw and Wild (like Vernon Brown before them, and like two generations of literary nationalists) at the University of Auckland.

\section{A city view}

Perhaps we are just not aware, yet, of the pleasures and satisfactions that can be enjoyed in a comely city.

Bill Wilson, 'Towards a Metropolis' (1961)

The Group would not have earned their reputation had they not built excellent houses that their owners still enjoy. But there are other factors, too. Importantly, they wrote: where local theory was thin on the ground, the Group (and more specifically Wilson) laid out a confident theoretical platform. Just as importantly, they went on to teach, so that in Auckland, where Allan Wild became Professor and Head of School in 1969 (a position that might as easily have been Wilson's were it not for his early death), a distinctly 'Groupish' line prevailed until as late as the $1980 \mathrm{~s}^{52}$ (The University of Auckland, it should be noted, held the country's only professionally recognized school of architecture until 1975). Perhaps most crucially, the Group appeared in a place where the culture anticipated them, a site prepared not just by the housing crisis and a widespread postwar fascination with building, but also by that first wave of writers and painters who had begun to groom an audience alert to nationalist ideals and willing to rise to a certain level of modernist experiment. Little wonder, then, if formalizing the Group's presence in the cultural nationalist canon appears to reconfirm what we already know. In their homespun modernism - plain, economical, rational, responsive, bare-handed and protestant - we find nationalist aesthetics as Curnow taught them 'driven home' in the 1950s.

And yet to build a modern nation you have to build cities. In reminding us of this, the Group asked questions that don't yet have clear answers. Their corpus in the end may be more house-bound and more suburban than their rhetoric promised. Nonetheless, for a literary reader, to wander through this neighbouring precinct raises questions which feel at once obvious and oddly unfamiliar.

When I look up from the desk where I'm writing, on the comely slopes of Mt Victoria, I'm lucky enough to have a panoramic view of Te Aro. 
I can try to imagine the inner city slum described by Firth in 1936. I can try to reconstruct what those summer school students saw when they surveyed it in 1948-49, conceptually bulldozed, ready for the imprint of their lunar (somewhat scary) Corbusian futurism. Mostly, though, in my idle moments I tend to check in with my personal favourites: buildings I like, or buildings that resonate with whatever I happen to have been reading or writing about. Nearest at hand is Jim Beard's Hannah Playhouse, whose brutalist hard-hat demeanour delighted Helmut Einhorn..$^{53}$ Circling counter-clockwise I get a glimpse of the Mrkusich panels, like a great banner headline along the street frontage of Te Papa, and wonder what Francis Pound would say about this modernist branding of the Fortress of National Culture. Rising above the Terrace are Wild's Jellicoe Towers; left, the marine hues of Athfield's Telecom House. Further left again I look for the white modernist slabs: Dixon Street, recently face-lifted; the Gordon Wilson Flats; and beneath them the (formerly white) McLean Flats, vestiges of Plischke and Newman now rather dwarfed and diluted. I note, idly, that the fauvist red of Athfield's School of Architecture and Design could be taken as a nod to its not-so-distant ancestor the Tomato House. And I recall indignantly as I complete my circuit that the Te Aro Re-planners would have bulldozed the Basin Reserve ('heritage' came later to the Architectural Centre, but that's another story).

My point, and I'm sure I could make the same point were I looking not at Te Aro but at Freeman's Bay, is that somehow, between Cedric Firth's time and ours, or between Bill Wilson's time and ours, we have learned to love the City. And yet, from where I'm sitting, the history of our learning to love it appears tacit and fugitive. The history that unravels out of literary nationalism makes a potent and indispensable story: how the settler hero struggled for a sense of possession of an unpeopled landscape, built a myth and a high culture, and then began to discover (as Baxter discovered, going bush at Jerusalem) that the settler hero wasn't alone, and that in someone else's history he wasn't the hero at all. It's a good story, this, but it's too thin, too linear (it reminds me of the solo dotted footprints of McCahon's 'beachwalk' paintings). It seems almost to be staged in a parallel dimension to the history that's implicit in those superimposed versions of Te Aro that is, the history of a quantum complexification of our urban culture in the decades after World War Two. So what can we learn from putting architecture (and planning) in the place reserved conventionally for poetry in the genealogy of our self-invention? And what happens then back 'home' on the ground of literature? Returning to cultural nationalism as the Phoenix generation initiated it, by way of this long detour through their younger Auckland familiars, I find myself thinking again about the Fifties, and how we need to back-fill that chapter in the narrative. If we travel slowly through that ill-mapped decade, and from there look more carefully at the 


\section{Journal of New Zealand Studies}

Forties in turn, might we find - somewhere along that lonesome, nationalist highway - exits by which to access a more urbane cultural history?

1 I am extremely grateful to the J.D. Stout Trust for the Fellowship that enabled me to research and write this essay. For sharing their recollections, my thanks to Jim Beard, Bill Toomath and Allan Wild; and for advice, materials, and instructive conversation, to Sarah Cox, Julia Gatley, Peter Shaw, Robin Skinner and Linda Tyler.

2 Paul Walker and Justine Clark, 'Everywhere and Nowhere: The Group and the New Zealand Architectural Canon', in Julia Gatley, ed., Group Architects: Towards a New Zealand Architecture, Auckland, 2010, pp.217-25.

3 Bill Wilson, 'The Small House', Kiwi, 43 (1948); reprinted in Douglas Lloyd Jenkins, ed., New Dreamland: Writing New Zealand Architecture, Auckland, 2005, p.147. The point is underlined in Lloyd Jenkins' admirable At Home: A Century of New Zealand Design (Auckland, 2004) by an editorial mishap. Setting out to quote the same remark from Wilson's essay, the text mysteriously substitutes Allen Curnow from three years earlier: 'New Zealand doesn't exist yet, it remains to be created, should I say invented ...' (p.177).

4 'The Cause of it all', Phoenix, 1,1 (1932), unpaginated.

5 Reprinted in Gatley, ed., Group Architects, p.22.

6 Julia Gatley and Bill McKay, “"Overseas Solutions Will Not Do": Calls for a New Zealand Architecture', in Gatley, ed., Group Architects, p.21.

7 Julia Gatley, 'Who was Who in the Group?', in Gatley, ed., Group Architects, pp.10-19.

8 Ben Schrader, We Call It Home: A History of State Housing in New Zealand, Auckland, 2005, pp.24-25.

9 Housing in New Zealand, short feature from the National Film Unit, 1946.

10 E.A. Plischke, About Houses, N.Z. Services Current Affairs Bulletin, 1, 20 (1943); republished as Design and Living, Wellington, 1947.

11 Christine McCarthy, 'The Roaring Forties: Reforming Architectural Education', in Gatley, ed., Group Architects, pp.29-30.

12 Ibid., pp.29-33.

13 W.D. Wilson, 'A Century of New Zealand Housing', New Zealand Herald (NZH), 1 November 1961.

14 Denys Trussell, Fairburn, Auckland, 1984, pp.147-8.

15 Ian Richards, To Bed at Noon: the Life and Art of Maurice Duggan, Auckland, 1997, p.122.

16 Alex Calder, 'Unsettling Settlement: Poetry and Nationalism in Aotearoa/New Zealand', REAL: Yearbook of Research in English and American Literature, 14 (1998), p.169.

17 Gatley, ed., Group Architects, p.22.

18 Jenkins, ed., New Dreamland, p.147.

19 Ibid., pp.151-2.

20 Francis Pound, The Invention of New Zealand: Art and National Identity 1930-1970, Auckland, 2009, pp.329-31. 
21 Allen Curnow, Introduction to A Book of New Zealand Verse 1923-45, in Peter Simpson, ed., Look Back Harder: Critical Writings 1935-1984, Auckland, 1987, p.47.

22 Paul Clark and Justine Walker, Looking for the Local: Architecture and the New Zealand Modern, Wellington, 2000, pp.27-28.

23 Gatley and McKay, 'Overseas Solutions', p.27.

24 Julia Gatley, Introduction, in Gatley, ed., Group Architects, p.1.

25 A.R.D. Fairburn, 'By Way of Introduction', Planning, 1 (1946).

26 A.R.D. Fairburn, 'Another Student House', New Zealand Listener, 12 May 1950; reprinted in Jenkins, ed., New Dreamland, p.157.

27 Bill McKay and Julia Gatley, 'Buildings for the Sub-tropics: The Group and Other Moderns', in Gatley, ed., Group Architects, p.201.

28 See Robin Skinner, 'Niki down under: impressions of Pevsner in New Zealand', in Philip Goad and Julie Willis, eds, Loyalty and Disloyalty in the Architecture of the British Empire and Commonwealth, Auckland, 1996, pp.102-10.

29 Comprising Penman, Wilson, Craig, Rotherham, Juriss and Wild. Gatley, 'Who was Who', pp.8-9.

30 Wystan Curnow, personal communication.

31 John Newton, 'Allen Curnow at Joachim Kahn's', Landfall, 220 (2010), pp.25-26. In the early 1950s Jack Abbott and Trevor Murphy bought the Group Construction Company from Robert Penman Snr. Under the name Murphy Abbott they built a number of Group houses. Gatley, 'Who was Who', p.9.

32 Fairburn, 'By Way of Introduction', p.5.

33 Fairburn, 'Another Student House', pp.154-61.

34 Gatley, ed., Group Architects, pp.9, 42.

35 Kai Jensen, Whole Men: The Masculine Tradition in New Zealand Literature, Auckland, 1996.

36 Quoted in Walker and Clark, 'Looking for the Local', p.73.

37 Pound, pp.178ff.

38 Curnow, discussing Holcroft, quoted in Pound, p.180.

39 As early as 1926, 64\% of the New Zealand population could be considered urban. Caroline Miller, 'Town Planning in New Zealand: The Formative Years of the Discipline', Planning Quarterly, (December 2002), p.12.

40 Cedric Firth, 'Problems of Working-class Housing', Tomorrow, 4 issues from 5 August 1936; reprinted in Jenkins, New Dreamland, p.89.

41 Firth, in Jenkins, New Dreamland, pp.89-90.

42 Jack Lasenby, 'A Clearing House for the Arts', Architecture New Zealand, (July-August 2001), p.93.

43 W.D. Wilson, 'Art and Architecture: Place for Beauty in a City', NZH, no date, Sheppard Collection File W754, Architecture and Planning Library, University of Auckland.

44 Julia Gatley, 'Wilson, Francis Gordon', in The Dictionary of New Zealand Biography. Te Ara - the Encyclopedia of New Zealand, updated 1 September 2010, http://www.TeAra .govt.nz/en/biographies/5w36/1.

45 Julia Gatley, 'Privacy and Propaganda: the Politics of the Dixon Street Flats', Interstices, 4 (1995), pp.1-11. 


\section{Journal of New Zealand Studies}

46 Paul Walker, 'Order from Chaos: Replanning Te Aro', in John Wilson, ed., Zeal and Crusade: The Modern Movement in Wellington, Wellington, 1996, p.83.

47 Walker, p.81.

48 Gatley, 'Who was Who', pp.18-19.

49 Julia Gatley, The Public and Commercial Realm', in Gatley, ed., Group Architects, p.146.

50 Ibid., pp.152-3.

51 The most important name not captured by this demographic is George Porter (b.1921).

52 McKay and Gatley, 'Buildings for the Sub-tropics', p.202.

53 Christine McCarthy, 'Hannah Playhouse (also known as Downstage)', in Julia Gatley, ed., Long Live the Modern: New Zealand's New Architecture 1904-1984, Auckland, 2008, p.189. 